\title{
Effect of Fortified Nursery Media with Bioagents in Nursery Production of Black Pepper (Piper nigrum L.) Varieties
}

\author{
Divya Seetaram Bhat ${ }^{1}$, N.K. Hegde ${ }^{2}$, Laxminarayan Hegde ${ }^{3}$, M.J. Manju ${ }^{4}$, \\ K.M. Shivakumar ${ }^{5}$ and P.S. Mahantesh ${ }^{1^{*}}$
}

${ }^{1}$ Department of Plantation, Spices, Medicinal and Aromatic Crops, College of Horticulture, Sirsi, Karnataka - 587104, India

${ }^{2}$ Department of Plantation, Spices, Medicinal and Aromatic Crops, UHS, Bagalkot, Karnataka - 587104, India

${ }^{3}$ Horticulture Research and Extension Centre, Sirsi, UHS, Bagalkot, Karnataka - 587104, India

${ }^{4}$ Department of Plant Pathology, Horticulture Research and Extension Centre, Sirsi, UHS, Bagalkot, Karnataka - 587104, India

${ }^{5}$ Department Soil Science and Agricultural Chemistry, UHS, Bagalkot,

Karnataka - 587104, India

*Corresponding author

\section{A B S T R A C T}

\begin{tabular}{|l|}
\hline Ke y w o r d s \\
$\begin{array}{l}\text { Black pepper varieties, } \\
\text { Bioagents, Fortified } \\
\text { nursery media and rooting } \\
\text { behaviour }\end{array}$ \\
\hline Article Info \\
\hline $\begin{array}{l}\text { Accepted: } \\
\text { 04 July 2018 } \\
\text { Available Online: } \\
\text { 10 August } 2018\end{array}$ \\
\hline \hline
\end{tabular}

\begin{abstract}
Nursery trial was conducted at Horticulture Research and Extension Centre, Sirsi (UHS, Bagalkot), Uttara Kannada district during October 2016 to June 2017 to assess the Effect of fortified nursery media with bioagents in production of black pepper rooted cuttings. The trial was laid out in factorial randomized block design replicated thrice with two factors viz., media (fortified nursery media enriched with Trichoderma + VAM), control (nursery media i.e., with soil and FYM in 1:1 without enrichment) and variety (ten varieties of black pepper viz., IISR- Shakti, IISR-Thevam, Panniyur-1, Panniyur-5, Ademane pepper, Shubhakara, Kurimalai, Karimalligesara, Vadakkan and Sigandini). Days to first sprouting (4 days), days to fifty per cent sprouting (18.33 days) were higher in the variety Panniyur-1 raised in fortified nursery media. First leaf emergence (18.33 days), number of roots per cutting (37.33) and fresh weight of roots (139 mg/cutting) were higher in the variety IISR-Thevam raised in fortified nursery media.
\end{abstract}

\section{Introduction}

Black pepper of commerce is the matured dried berry and is valued for its aroma contributed by the essential oil, present in the fruits and the pungency due to its alkaloid piperine. It is mainly used as culinary item in processing food industries, perfumery, allied industries and in traditional medicines. Black pepper is widely used spice in the world and has occupied a prime place in the cuisines of both East and West. It is an indispensable item in the preparation of processed meat, sauces, soups, curry powders and pickles. From 
medicinal point of view it is used as a carminative, stomachic and febrifuge. The major economic products are black pepper and white pepper. Other value added products like pepper oil and oleoresins find increasing use in food industries of developed countries. Besides some new forms of pepper like preserve green pepper in brine, vinegar, dehydrated green pepper, etc. are becoming popular. Hence, black pepper is also called as 'Black gold' on account of its economic importance.

Black pepper is being largely grown in India, Indonesia, Malaysia, Brazil, Thailand, Sri Lanka, Vietnam and China. India is the major producer of black pepper with an area of 1.28 lakh hectares and production of 64,000 tonnes with a productivity of $502 \mathrm{~kg}$ per hectare.

The total area and production of spices in the country is 33.17 lakh ha and 61.08 metric tonnes, respectively. Variations in productivity among different black pepper producing countries is Indonesia (622 kg/ha), Malaysia (1500 kg/ha), Brazil (2075 kg/ha), Thailand (1375 kg/ha), Sri Lanka (849 kg/ha), Vietnam (2301 kg/ha) and China (1160 kg/ha) (Anon., 2016).

Present trial is carried out to assess the rooting behaviour of black pepper varieties in fortified nursery media compared to normal media. Cuttings raised in fortified nursery media enriched with Trichoderma, VAM and neem cake is well-known to grow better than that of normal media (Wimalarathne et al., 2014). Due to the increased demand in the global market for black pepper, there is a need to produce of good quality planting material.

So, the present trial was planned to produce good quality black pepper rooted cuttings and to assess the effect of fortified nursery media with bioagents in nursery production of ten black pepper varieties.

\section{Materials and Methods}

The present trial was carried out in poly tunnel laid out in factorial randomized block design with two factors viz., media (fortified nursery media enriched with Trichoderma + VAM), control (nursery media i.e., with soil and FYM in 1:1 without enrichment) and variety (ten varieties of black pepper - IISR- Shakti, IISRThevam, Panniyur-1, Panniyur-5, Ademane pepper, Shubhakara, Kurimalai, Karimalligesara, Vadakkan and Sigandini). Single noded stem cuttings of black pepper were raised in root trainer (12 cells of $300 \mathrm{cc}$ capacity). The observations were recorded daily in the initial stages and at thirty and ninety days interval. Fifteen plants were selected randomly and days to first sprouting, days to fifty per cent sprouting, number of leaves per cutting were recorded. At ninety days after planting, Cuttings were taken out of root trainer i.e., destructive sampling to record number of roots and fresh weight of roots.

\section{Results and Discussion}

Days to first sprouting (4 days), days to fifty per cent sprouting (18.33 days) were earlier in the variety Panniyur-1 raised in fortified nursery media. First leaf emergence (18.33 days) was recorded by the variety IISR-Shakti raised in fortified nursery media (Table 1).

Number of leaves per cutting was found to be non-significant among different varieties. Maximum number of roots per cutting (37.33) and fresh weight of root (139 mg/cutting) observed in the variety IISR-Thevam raised in fortified nursery media.

Between two types of nursery media, significantly higher number of days to first sprouting and days to fifty per cent sprouting were observed in the fortified nursery media (5.80 days and 20.33 days respectively) compared to the control. 
Table.1 Effect of fortified nursery media on sprouting and leaf emergence in stem cuttings of black pepper varieties

\begin{tabular}{|c|c|c|c|c|c|c|c|c|c|c|}
\hline \multirow{2}{*}{$\begin{array}{c}\text { SI } \\
\text { No. }\end{array}$} & \multirow{2}{*}{$\begin{array}{l}\text { Treatment } \\
\text { Variety }\end{array}$} & \multicolumn{3}{|c|}{ Days to first sprouting } & \multicolumn{3}{|c|}{ Days to 50 per cent sprouting } & \multicolumn{3}{|c|}{ First leaf emergence (days) } \\
\hline & & $\begin{array}{c}\text { Fortified } \\
\text { nursery } \\
\text { media }\end{array}$ & Control & Mean & $\begin{array}{c}\text { Fortified } \\
\text { nursery } \\
\text { media }\end{array}$ & Control & Mean & $\begin{array}{c}\text { Fortified } \\
\text { nursery } \\
\text { media }\end{array}$ & Control & Mean \\
\hline 1 & IISR-Shakti & 6.00 & 6.67 & 6.33 & 23.00 & 23.67 & 23.33 & 20.67 & 23.67 & 22.17 \\
\hline 2 & IISR-Thevam & 5.33 & 6.33 & 5.83 & 19.33 & 20.67 & 20.00 & 18.33 & 18.33 & 18.33 \\
\hline 3 & Panniyur -1 & 4.00 & 5.33 & 4.67 & 18.33 & 20.67 & 19.50 & 21.33 & 23.67 & 22.50 \\
\hline 4 & Panniyur -5 & 5.33 & 7.00 & 6.17 & 19.67 & 22.67 & 21.67 & 20.33 & 22.00 & 21.17 \\
\hline 5 & Ademane pepper & 6.33 & 8.00 & 7.17 & 19.33 & 21.33 & 20.33 & 20.33 & 23.00 & 21.67 \\
\hline 6 & Shubhakara & 6.67 & 8.33 & 7.50 & 20.33 & 23.00 & 21.67 & 19.33 & 21.00 & 20.17 \\
\hline 7 & Kurimalai & 6.33 & 7.00 & 6.67 & 20.33 & 24.33 & 22.33 & 20.00 & 22.00 & 21.00 \\
\hline 8 & Karimalligesara & 6.00 & 6.67 & 6.33 & 21.33 & 23.67 & 22.50 & 19.33 & 21.33 & 20.33 \\
\hline 9 & Vadakkan & 6.33 & 7.67 & 7.00 & 19.33 & 21.67 & 20.50 & 19.33 & 23.33 & 21.33 \\
\hline \multirow[t]{2}{*}{10} & Sigandini & 5.00 & 6.67 & 5.83 & 21.33 & 23.33 & 22.33 & 19.67 & 22.67 & 21.67 \\
\hline & Mean & 5.80 & 6.90 & & 20.33 & 22.50 & & 19.87 & 22.10 & \\
\hline \multicolumn{11}{|c|}{ For comparison means of } \\
\hline & & S.Em \pm & $\begin{array}{c}\text { C.D. @ } \\
1 \%\end{array}$ & $\begin{array}{l}\text { CV } \\
(\%)\end{array}$ & S.Em \pm & $\begin{array}{c}\text { C.D. @ } \\
1 \%\end{array}$ & $\begin{array}{l}\text { CV } \\
(\%)\end{array}$ & S.Em \pm & $\begin{array}{c}\text { C.D. @ } \\
1 \%\end{array}$ & $\begin{array}{l}\text { CV } \\
(\%)\end{array}$ \\
\hline \multicolumn{2}{|c|}{ Media (M) } & 0.08 & 0.23 & 7.03 & 0.12 & 0.35 & 3.09 & 0.11 & 0.41 & 2.85 \\
\hline \multicolumn{2}{|c|}{ Variety (V) } & 0.18 & 0.52 & & 0.27 & 0.78 & & 0.24 & 0.94 & \\
\hline \multicolumn{2}{|c|}{$\begin{array}{l}\text { Interaction of media and } \\
\text { variety }\left(M_{x} V\right)\end{array}$} & 0.26 & 0.74 & & 0.38 & 1.09 & & 0.35 & 1.3 & \\
\hline
\end{tabular}


Table.2 Effect of fortified nursery media on number of leaves and roots and fresh weight of roots in stem cuttings of black pepper varieties at ninety days after planting of cutting

\begin{tabular}{|c|c|c|c|c|c|c|c|c|c|c|}
\hline \multirow[t]{2}{*}{$\begin{array}{l}\text { Sl } \\
\text { No. }\end{array}$} & Treatment & \multicolumn{3}{|c|}{ Number of leaves per cutting } & \multicolumn{3}{|c|}{ Number of roots per cutting } & \multicolumn{3}{|c|}{$\begin{array}{c}\text { Fresh weight of root } \\
(\mathrm{mg})\end{array}$} \\
\hline & Media & $\begin{array}{c}\text { Fortified } \\
\text { nursery } \\
\text { media }\end{array}$ & Control & Mean & $\begin{array}{c}\text { Fortified } \\
\text { nursery } \\
\text { media }\end{array}$ & Control & Mean & $\begin{array}{c}\text { Fortified } \\
\text { nursery } \\
\text { media }\end{array}$ & Control & Mean \\
\hline 1 & IISR-Shakti & 2.33 & 1.33 & 1.83 & 16.33 & 9.33 & 12.83 & 66.17 & 51.33 & 58.75 \\
\hline 2 & IISR-Thevam & 2.67 & 2.33 & 2.50 & 37.33 & 22.67 & 30.00 & 139.00 & 123.00 & 131.00 \\
\hline 3 & Panniyur -1 & 1.67 & 1.33 & 1.50 & 2.00 & 2.00 & 2.00 & 4.00 & 3.77 & 3.88 \\
\hline 4 & Panniyur -5 & 1.67 & 1.33 & 1.50 & 6.33 & 4.00 & 5.17 & 41.50 & 28.67 & 35.08 \\
\hline 5 & Ademane pepper & 2.00 & 1.33 & 1.67 & 8.00 & 4.67 & 6.33 & 25.83 & 22.33 & 24.08 \\
\hline 6 & Shubhakara & 1.67 & 1.33 & 1.50 & 20.33 & 12.00 & 16.17 & 44.67 & 38.00 & 41.33 \\
\hline 7 & Kurimalai & 1.67 & 1.33 & 1.50 & 6.33 & 4.00 & 5.17 & 50.00 & 37.33 & 43.67 \\
\hline 8 & Karimalligesara & 3.33 & 2.67 & 3.00 & 6.00 & 4.33 & 5.17 & 56.00 & 48.00 & 52.00 \\
\hline 9 & Vadakkan & 2.00 & 1.33 & 1.67 & 8.67 & 6.33 & 7.50 & 40.33 & 37.00 & 38.67 \\
\hline \multirow[t]{2}{*}{10} & Sigandini & 2.00 & 1.67 & 1.83 & 19.33 & 14.00 & 16.67 & 39.63 & 37.00 & 38.32 \\
\hline & Mean & 2.13 & 1.60 & & 13.30 & 8.63 & & 50.71 & 42.64 & \\
\hline \multicolumn{11}{|c|}{ For comparison means of } \\
\hline & & S.Em \pm & $\begin{array}{l}\text { C.D. @ } \\
1 \%\end{array}$ & $\begin{array}{l}\text { CV } \\
(\%)\end{array}$ & S.Em \pm & $\begin{array}{c}\text { C.D. @ } 1 \\
\%\end{array}$ & $\begin{array}{l}\text { CV } \\
(\%)\end{array}$ & S.Em \pm & $\begin{array}{c}\text { C.D. @ } 1 \\
\%\end{array}$ & $\begin{array}{l}\text { CV } \\
(\%)\end{array}$ \\
\hline \multicolumn{2}{|c|}{ Media (M) } & 0.09 & 0.28 & 28.34 & 0.13 & 0.38 & 6.59 & 0.25 & 0.73 & 2.98 \\
\hline \multicolumn{2}{|c|}{ Variety (V) } & 0.22 & 0.62 & & 0.29 & 0.85 & & 0.57 & 1.63 & \\
\hline \multicolumn{2}{|c|}{$\begin{array}{l}\text { Interaction of media and } \\
\text { variety }\left(M_{x} \mathbf{V}\right)\end{array}$} & 0.31 & NS & & 0.42 & 1.2 & & 0.81 & 2.31 & \\
\hline
\end{tabular}


It is attributed to the presence of Trichoderma and VAM which supplies good amount of nutrients and growth promoting substances to the planted cuttings, so that it can easily absorb the nutrients available in the nursery media compared to the nursery media.

Early sprouting in Panniyur-1 variety may be due to the varietal character of Panniyur-1 having early sprouting tendency and grow vigorously. The present findings are in-line with the findings of Tilak (1995) and Kandiannan et al., (2000) which states presence of VAM may increase plant acquisition of phosphorus and nitrogen thereby increasing the growth and yield of the plants.

Higher number of leaves and roots were also obtained in fortified nursery media (2.13 and 13.3 respectively) compared to control (1.60 and 8.63 respectively) at ninety days after planting (Table 2). It may be due supplement of more nutrients the presence of VAM. It must have increased plant acquisition of phosphorus and nitrogen thereby increasing the growth and number of leaves.

Among the varieties, Karimalligesara (3.33) and IISR-Thevam (2.67) raised under fortified nursery media recorded significantly higher number of leaves. This may also be attributed to the varietal character of having genetic potentiality to produce more number of leaves.

Fresh weight of the roots $(50.71 \mathrm{mg})$ was significantly higher in fortified nursery media compared to control (42.64 mg) after ninety days of planting of cuttings (Table 2). This may be due to the combined effect of Vesicular Arbuscular Mycorrhizae (VAM) and Trichoderma that helped in taking up of more amount of nutrients and hence the earlier growth and development. This finding is in-line with the studies of Kandiannan et al., (2000) in black pepper, Wimalarathne et al., (2014) in black pepper and Srinivasa Murthy and Narayanappa (2015) in ocimum. Treatment with VAM significantly improved the root characteristics and phosphorous uptake of pepper variety Panniyur-1 (Thanuja et al., 2002). Among the interaction of media and varieties IISR-Thevam produced higher number of roots and fresh weight of roots. This may be due to the varietal character of IISR-Thevam to produce good and healthy roots.

For better root and root characteristics, growing of black pepper in fortified nursery media enriched with bioagents is found to be beneficial. Among ten varieties of black pepper tested, IISR-Thevam grown in fortified nursery media produced quality planting material with good sprouting and rooting.

\section{References}

Anonymous. 2016. Spices Statistics at a Glance, Directorate of Arecanut and Spices Develpoment, Calicut, Kerala.

Kandiannan, K, Sivaraman, K., Anandaraj, M. and Krishnamurthy, K.S. 2000. Growth and nutrient content of black pepper (Piper nigrum L.) cuttings as influenced by inoculation with biofertilizers, J. Spices and Aromatic Crops, 9 (2): 145-147.

Srinivasa Murthy, K. M. and Narayanappa, M. 2015. Study of Growth Promotion Effect of VAM Fungi and Trichoderma Species on Medicinal Plant, Int. J. Recent Res. in Life Sci., 2 (2):58-63.

Thanuja, T. V., Ramakkrishna, V. H., Sreenivasa, M. N. 2002. Induction of rooting and root growth in black pepper cuttings (Piper nigrum L.) with the inoculation of arbuscular mycorrhizae, J. Scientia Horticulturae, 92 (3/4): 339346. 
Tilak, K. V. B. R. 1995. Vesicular-arbuscular mycorrhizae and Azopirillum brasilense rhizocoenosis in pearl millet in semiarid tropics In: Adholeya, A, and Singh, S., (Eds.) Proceedings of Third National Conference on Mycorrhiza, pp.:177179.
Wimalarathne, H.G.M.C., Sangakkara, U. R. and Sumanasena, H. A. 2014. Effect of Arbuscular Mycorrhizal Fungi (AMF) on shoot and root development of Black Pepper (Piper nigrum Linn.) rooted cuttings, Int. Invention J. Agric. and Soil Sci., 2 (6): 105-111.

\section{How to cite this article:}

Divya Seetaram Bhat, N.K. Hegde, Laxminarayan Hegde, M.J. Manju, K.M. Shivakumar and Mahantesh, P.S. 2018. Effect of Fortified Nursery Media with Bioagents in Nursery Production of Black Pepper (Piper nigrum L.) Varieties. Int.J.Curr.Microbiol.App.Sci. 7(08): 390-395. doi: https://doi.org/10.20546/ijcmas.2018.708.044 